\title{
Differentiation and Political De-Differentiation in the Periphery of the Modern Society
}

\author{
Raúl Zamorano Farías \\ Correspondence: Raúl Zamorano Farías, PhD Sociology of Law from the Center for Risk Studies at the University of \\ Lecce (Italy 2002). CETMECS-UNAM Circuito Mario de la Cueva s/n, Ciudad Universitaria, C.P. 14510, México. \\ E-mail: rzamorano61@gmail.com
}

Received: February 2, 2021

doi:10.11114/ijlpa.v4i1.5189
Accepted: March 11, 2021

Online Published: March 15, 2021

URL: https://doi.org/10.11114/ijlpa.v4i1.5189

\begin{abstract}
This work wants to analyze, from the theoretical-conceptual architectural frame of the General Theory of Social Systems (TGSS), and problematize the relationships and the logical articulations between the system of politics, economics and law to observe what have been the hetero-descriptions of the democratic state in the periphery of modern society (1).

The processes of functional differentiation characterizing the institutionalization of structures and expectations normative, cognitive - in the evolutionary becoming of the State-nation, in Latin America, stabilized the logic of the patrimonial political centralism, so that the history of innumerable legal-political and economic reforms have been used rather to perpetuate the status quo than to change something (2). It's interesting to observe, for this reason, the developing of many forms of coordination and social development to achieve the desired modernity in the continent, from the presidential caudillism, Cepalian developmentalism (1950), military praetorianism (1970), till the forms of economical laissez faire (1990). These models have basically revolved around the valorization of the clientelistic political regime as a central space for the construction of democracy and the market (3). In this context, cognitive and normative expectations (law) have not managed to generate lasting political accommodations that facilitate sociopolitical evolution, where corporations, families and clientelistic caudillism continue to prevail, except the institutionalized expectations (4). The question then is not how 'democracy should be', but how is this possible in this periphery of modernity.
\end{abstract}

Keywords: Modernity, Periphery, Complexity, Differentiation, De-Differentiation, expectations

\section{Introduction}

The analysis and observation about the semantics of the democracy and its evolution in modern society must contemplate the relevant change of the meaning of policy in the course of the last decades, recovering the old discussion and installing it in the complexity of the contemporary society. In this sense, from a glance that does not ignore its origin, but that assumes it.

On the matter, the reflection is particularly interesting about the democracies in the periphery of the modern society and the always difficult relation between the economic system and the right. In the events occurred in these last months in Latin American, it is possible to observe that the demand to do to the State, is indeed, not to allow the operation of the right as an independent subsystem and the question that inevitably arises is how possible this can be realized.

The democracy, consequently, is used to cover different concepts and operative ways, while the democratic theory continues thinking to the State coincidenting with society (almost as its synonymous) or, at least, like its worth expression, refusing to confront itself with versions that give capacity to a greater complexity of society and of its subsystems.

Indeed, the theoretical reflection that considers the self-reference of the social systems, its structural determinism and the demonstrated incapacity to let itself irritate for those things that do not make resonance in its structures leads to systems that attribute themselves the priority. The democracy, then, appears under a different look and only politically it can be discredited. But, again, the fears of ungovernability, acephalia, coupe d'etat (Mexico, Brazil, Venezuela) that becomes to wake up, generate doubts difficult to dissipate. 


\title{
2. Adversus Modernus
}

\begin{abstract}
Schließlich würde ich an to deiner Stelle den Herrn Demokraten in general bemerken, daß sie to besser täten, sich erst mit to der Bourgeoisliteratur selbst bekannt zu machen, ehe sie sich unterfangen, gives to Gegensatz zu derselben anzubellen.
\end{abstract}

K. Marx

(Brief nach J. Weydemeyer. März 5, 1852)

The unfolding of modernity entails accelerated processes of functional differentiation that increase the dynamism of the society. Throughout the evolution this process brought to a gradual increase of social differentiation that has taken to the constitution of partial systems, but also in an agudization of the phenomena of disintegration, fragmentation, inclusion and exclusion.

From this point of view the social system is, in fact, conceived as a mechanism of reduction of the world complexity through a delimitation of what assumes importance inside the system. Exactly, it is just this plurality of implications and the totality of the events what makes imposible a global perception of the world (Luhmann, 1990; 1995; 1996; 1998a; 2007; Zamorano Farías, 2003).

We spoke, in general, of differentiation when a system becomes different from its surroundings drawing its differentiated limits, making possible to observe that other systems exist in its own surroundings.

For example, in the surroundings of the society exist psychic systems and organic systems. The differentiation of the surroundings does not depend on the system, nevertheless, assumes particular forms according to the distinctions that orient the observation of the system. The form of differentiation establishes the way in which the global system carries out the relation among the partial systems; it has relation with the difference among systems that are each other in their environment (Baraldi, 1996: 56, 57; Luhmann \& De Giorgi, 1996: 58). The functional differentiation articulates the society, based on the division of the work, in different subsystems with complex and specific functions, and so enlarges the social complexity (Zolo, 1997: 248; Luhmann 2007). The binomial system/environment is an operation supported in a difference (Spencer Brown, 1979).

Now, the central characteristic of this process is that each function that takes part of the differentiation scheme serves only for a partial system of the society.

In another way this form of differentiation would not be made and although, evolutionarily, it was possible to speak of division of the social work, differentiation of roles or of a multiplicity of semantic distinctions it would be implausible to affirm a functional differentiation of this type; every time the factor that makes possible to operate this differentiation is the communication.

If we went back to middle age this form of the differentiation is still not carried away. There were many fields for the truth; for example, the religion, the philosophy, the rhetoric; there were also different monetary systems, for the local commerce, others for the foreign commerce; there were different political regimes, in the plane of the empire, in that of the States' territories, and in the Church's one. Evidently, the relations between these diverse partial planes of functional rationality were correspondingly complicated. Nevertheless, the social order did not depend on this situation; it was guaranteed by the stratification, which is gradually abandoned once increase the difficulties of coordination of the society. The passage towards the primary differentiation for functions was dominated -in front of the previous order- in the structural and semantic plane by the differentiation's way and the constitution of the State-Nation, territorial and politically sovereign (Luhmann, 2004: 1-5).

Sovereignity that was not only understood as 'indipendence' respect to other political powers, as the empire or the Church, but as the capacity of the sovereign State to respond, in a territory clearly delimited, to all the problems and whose solution demanded that the political power was concentrated. Luhmann indicates that in the early Modern Age was made a tentative of introducing a combination of universalism and specification as the universal capacity of autonomy in each one of the functional fields of the partial systems of the society. This was the only way to face with political methods against wars around the truth. That is to say, controlling the violent disputes of the controversies caused by the scientific or religious questions (Luhmann, 2004: 5; Zamorano Farías, 2003).

Advancing in the time, around the second half of eighteen century, the sociopolítical semantics of Europe totally revolutionizes with the predominance of the illustrated speech and with the imperative of the reason, conserving itself almost without significant changes, knowing that the installation of the Social State and the State of well-being, in ninteen and twelve century respectively, will be the only really novel receptions until end of the century with exception, of course, of the wars and the daily slaughter that have characterized last the last hundred years.

In this way, during both the last two centuries modernity and society have been structured and oriented by the principles 
of the illustration that through the crystallization of great objectives, explicited already from the Renaissance, outline the illuminist thought, which promoted the modern State that finished separating the policy from the sacred conceptions, exceeding the absolutism to place people as the subject par excellence of politics, restarting, with the French Revolution, the history of the world.

The society has been temporarily observed and differenciating itself through these historical semantics, in relation to its interior, to build the difference with the environment. These representations of the difference, that sediment, have produced a specific patrimony of the difference in each phase of the historic evolution (Christian/pagan, noble/plebeian, capitalist/proletaries, developped/underdevelopped). (Zamorano Farías, 2003; 2004; Luhmann \& De Giorgi, 1996).

Indeed, this fact guides us to consider the question of the different descriptions and forms in which the modern society has been constructed and also how this evolutionary process has increased to the uncertainty and a feeling of neglect, whose origin is in the intrinsic logics of inclusion-exclusion to all process of differentiation.

Nevertheless, the continuous political ideology oriented in agreement to the contained registration in old social contracts, without asking itself, in what measure, the same idea of social contract in the framework of a growing decentralization of the political action, can be in force. Moreover, the same classical distinction used in the framework of the political sociology, among policy/society, that remits philosophically to the distinction among public space of the political life and the domestic economy whose ethical component is affirmed in a supposed human nature oriented toward its perfection in the political community (good life), is already inadequate and even sociologically, the philosophical concept of the koinonía politiké (as its modern meaning: 'civil society') turns out to be insufficient. Generally and in its simpler expression, this distinction wants to indicate the existing distance among the people that perform its duties in the environment of the formal organizations of the political sphere and all the individuals that are considered as constituting 'the society' and are external of these organizations (and where, frequently, one can finish wagering and taking position for the supposed normative attributes of 'the society' considerer as opposite to a policy characterized by its corruptibility).

Currently it is not possible to understand the policy as a system that 'opposes' or that 'controls' the society, but as a distinction that happens in itself: as a new system in an environment. The policy is, therefore, always policy of the society, still in the periphery of the modern society.

This situation that becomes more evident, and dramatic, in Latin America where the referent of the modern society, that in our continent never crystallized totally, is affected by significant structural changes (displacement to a tertiary economy and different impacts that generates the outcoming globalization) and where the reflection on policy of the continuous contemporary society anchors in the preoccupations for the totality, for the great constructions on the world but not in the necessary compensations that are generated in the simultaneity and contingency of the decisions -or nondecisions- (complexity) that this process of differentiation and globalization triggers (Luhmann \& De Giorgi, 1996).

Now, what are the conceptual limitations and difficulties that are derived from such understanding of the society?

The weight of the theoretical tradition, that accustomed us to observe the society from outside becomes problematic and already impossible to this height, because it is stated that outside society there is nothing. If society's operating has specific characteristics and everything that occurs, simultaneously occurs, then the modern society always operates in the present and through each event produces the difference between past-future, constructing in this way structures of decisions that always are taken in the only known time, in the simoultaneity of the present (Kosellek, 1986). Furthermore, by the modification of the geographic distances (border) and socials (economic) the policy no longer operates only in the national but also in the global and local sphere putting in tension the classic space of the policy; the national sovereignity.

This acceleration, that has affected the historical background of the conscience, is only diluted in projections without imaginary images nor being here and now (the sense of the future is lost), which makes difficult to put the present in perspective also affecting the political system, that seems to have less and less capacity to satisfy the demands. All the context generates a geometric increase of the complexity, which evidently excludes also every possibility and deontology.

We will remember that for many centuries the different social organizations functioned in a remote way, that is to say closed, but already since the XV century, with the European expansion after the 'discovery' of America, the society becomes a world system. (Wallerstein has taken up again this Marx's idea; the world system has as support the birth of the world economy).

For this reason, the only possibility is to indicate the society as the result of its own operations which, through its operating, continuously reproduce the difference with its surroundings. That is to say, the object of the observation is 
constructed through those operations and, precisely, it is this character determined by the continuous production of the difference and auto-observation which allows us to know how the modern society can be observed, and how the democracy can be realized.

The classical ontology cannot give account of these phenomena because the own structure of the modern society broke to pieces. The contingency, where all is improbable but possible to be brought up to date, is the introduction of the historical nothing, because it can always be otherwise (there is not teleology). The updating of the nothing is the observer (the operation that realizes), the third excluded (for example, in painting the observer's perspective does not appear in the picture but it's what makes the difference). Interesting result, in such sense, the contributes of the sociological theory of the social system, as a capable theoretical tool to escape to the limitations and difficulties. Luhmann advances the idea that the system is distinguished from the environment with a base only in communicative operations (Luhmann, 1991, 1996; 1998a).

At the moment and in an extremely complex world where the margin in the tension of the intentional experience and acting also is extremely reduced, the superabundance of possibilities always surpasses what we are able to elaborate through the action and experience (Luhmann, 1991). However, this means and supposes a condition of uncertainty respect to the external reality. Uncertainty that talks about the superabundance of possibilities not realized by experience and to the relative risk of realization of a possibility between many. We can call the first as the complexity and the second contingency.

The complexity comes thus imposing the necessity to choose between a plurality of options, there where the contingency evidence that that election had been able to be done otherwise, exposing the system to the risk of the choosed selection (Luhmann \& De Giorgi, 1996, particularly chapter V). In this theoretical perspective, the social systems develop the function of reducing the world's complexity, mediating between the extreme indetermination of this one and the law potential of the sense of the experience and the action. The social systems attenuate then to the own difficulty of the complexity of the world delimiting the selection of the present possibilities of the experience in this one (Luhmann, 1973: $81 \mathrm{ss}$; 1985).

But a system not only reduces the complexity of the world but through the selection of the possibilities equipped with sense, creates a demarcation with its surroundings. It is defined then a difference that is the difference system/environment, in whose base the selectivity of the system will make possible in its interior only those actions that can be important to it. So, a specification of the complexity of the world is produced, where the problems are identified as problems of the maintenance of the system(s).

The concept of complexity signifies that the world offers to man a practically unlimited quantity of possibilities of experience and of action to which corresponds a very reduced capacity to perceive, to devise information and to act. The complexity, thus understood, is an excess of the possibilities of the world; that is to say, the difference among the number of the potential possibilities and of their brought un number. In this sense the complexity signifies a need of selection. More specifically, is called as complexity $i$ ) the number and the variety of the elements of a system; $i i$ ) the extension and the incident of the relations of interdependence among the elements of a system and iii) the variability in the time of the elements and its relations (Zolo, 1997: 245, 246; Luhmann, 2007).

\section{Complexity and Policy of the Modern Society}

It is absolutely evident that in a social reality, where it is increased the differentiation and the dynamism, born distortions and mix-ups (between expectations and norms) that mines the credibility and confidence between elites governing and citizens, but also, as it has been indicated, that the phenomena of exclusion and social disintegration are becoming gradually serious, fundamentally in the peripheries of the modern society.

The modernity builds its own image and what does not enter in this image is considered as its periphery, which does not signify, in any of the cases, that in this type of differentiation the center is more important than the periphery. It would equal to apprehend this form of differentiation in a false way, according to the model of relation for hierarchical ranks (Luhmann, 1998, 2007; Luhmann \& De Giorgi, 1996).

So, our Latin American periphery of XXI century, even though is not the same one, returns to meet with its old problems. After twerty years, characterized by globalization and neoliberalism, begin to emerge the same problems of the XX century as if it was an endemic disease. The ninety, which happened to be denominated as 'lost decade 'for the drag of the foreign debt, crash with the dawn of the new millenium and discover with disappointment that the executed economic policy did not manage to smooth the miseries. Perhaps the region is richer than before when observing the statistics of the internal product, but this argument anyway does not solve the exclusion, the high unemployment, the social insecurity, the precarious job, the poverty and, less still, the fragile institucionalism and civilization of the expectations. 
Now when the social order introduces a communication, a fold of objectivity of the human behavior; dissociating the immediate communication of every commitment, of every appraisal metaphysics, civilizes the expectations opening all a stripe of social differentiated evolution (change) and that "objectivises" in a norm. This supposes the social indifference of the individuals set against that social order. That is to say, assumes a luck of depersonalization of what is personalized (paradoxically personalized through the expectation of $\mathrm{x}$ civilization), creating the order of the characteristical indifference of the modernity (the rights of the man or the individual guarantees in the State of right). The functional process of differentiation is, in last instance, a domesticated contingency, where the proclamed create the subject, are for the subject (Hegel), without principles neither hierarchical articulation (it is a philosophy of the postkantian history where the justification has not been found from a rational or metaphysical judge). This social differentiated differentiated, to what we arrived, is an order that is handled in the environment of the expectations (symbolic horizon).

If the differentiated social order creates a civilization of correlative expectations that make possible, indeed, that differentiated social order, the fundamental point is a sense of objetivation of the indifference before a differentiated social order, otherwise what makes chips this differentiated order is the stratified corporationism, which cannot, nor has the function, represent all the society. Behind this there is a process that generates its own subproducts that institutionalize (as for Norbert Elías), but this process is against the representalism, because the social tasks are an emergent construction (Hegel) and not transcendental representations (Kant).

Nevertheless, in the continent, facing these processes the political system seemed to have lost capacity of controlling the diverse expectations and phases that carries the modernity, characterizing itself by it delay in the forms of making and thinking the political question and by the traditional and state positions of the elites (where there is not a clear idea of the new role and the restrictions that open the process of modernization). It is as if the policy did not have sequentially time to observe and organize its own operations. Therefore, it is not unprobably that to a world-wide and continental scale is lived an estrangement phenomenon and, also, a certain malaise for the political question.

Today it is a common place to declare that the developed contemporary societies founded their profits on the increasing civilization of the expectations and the consequent extension of the individual rights, on the generalization of the democratic forms of government, on the allocation of resources on the base of the market, on the scientific and technological knowledge and in the instrumentalization of the social bonds by formal organizations; which, it is certain, every time this process has been associate with a marked differentiation in partial systems that come unfolding without recognizing restrictions, except for those contained in their own structures and that make reference to auto referential operations (Luhmann, 1991).

However, the impact and the transformations of the revolutions of final XVII century and the principles of the XIX in Europe and the United States did not arrive at these coasts, on the contrary, apparently they imposed to Latin America a heavy structure of government that prevented to go towards the political and social evolution. It is as if the great revolutionary wave that swept to the Atlantic world deposited a set of practicable rules only in Europe and the United States, and defective institutions in the rest of the Latin American republics, because unlike the European societies, whose process of functional differentiation was a pattern of social organization of a polycentrical type, where the social systems operate decentralized and independently although in a connected way, our societies have been characterized to be structured around a centralized system, dominant and authoritarian.

In such direction in Latin America, and behind the discussion on modernity and the policy, starts at the moment another historical discussion that accompanies its development and evolution: the modernization. In the continent the privileged instance of the sociopolitical coordination was and has been the State. Let us remember, as Whitehead indicated (1998), that between 1930 and the principles of the Eighties, the great State of the social centralized commitment (welfare) became the norm in all the region from the model devised by the Mexican constitution from 1917. This, in a scene where the different social sectors historically exhibited a lower propensity to the moderation and the political prudence to the exposition of its demands and, where also, elites' leaders showed their irresponsible demagoguery guaranteed by the representative institutions, that operatively have been incapable to authenticate and to canalize the overflowed expectations of a tumultuos citizenship.

The State, as it has been indicated, functioned as the motor of the economy and the industrialization. Takes a walk to some abstract and generalizing ideas of universal application, a kind of economical "new-modernism" where the retoric of democracy returns to be central. On the matter, for example, protected by the constitutional designs the new rights have become, generally, in the facade of the central authorities to buy loyalties, beside the characteristical question in the continent, because, also historically, the failure of the law in front of the authoritarian structures can be explained, partly, for the absence of a social mobilization in favor of the reforms and for the instrumentalization of this one by the classes in power. As Langley indicates, the liberal ideas have been historically shared only by the elites, while the 
masses, when were mobilized in favor of the independence, had to be controlled to avoid that the new republics left control (Langley, 1996).

This type of social coordination, that was based on the existence of a public administration, a state of right and in a classical idea of the influential state, leaned on a certain conception of sovereignity, every time that supposed a clear difference between society and State, where the centralization of the power in the State as a legitimated instance of domination as recognized authority, would operate as the vertex of the society. In this way there were forming and inter-penetrating logics of the making policy that sent to certain common institutions in the area; the paradigm of the rational planning, whose higher expression was the developping State between the Forties and Sixty of the past century.

This rationalizing intervention of the State, that in the language of Lechner, estimates a social reality of little complexity so that the reciprocity norms are applicable; that is to say, the supposition of a system composed of reciprocal actions between individuals in a chain of simple causality and an obedient execution of the measures, is a conceptualization that rests in the conviction that the aims, the means and criteria are clearly determined and prioritized, and that the individual action adds without fissures after the attainment of the objectives and collective aims (Lechnert, 1988; 1995). But this conception of the total coordination of the society through the integral planning crumbled, because it no longer worked as the narrative of history (meta-speech as an existential reference for its own time). In this way the deposited hopes in the political planning and its predictive capacity crash, observing that the modernization does not conclude, in the region, neither with the revolution nor with the mentioned development.

Indeed, at the present time, the limitations of the classic conceptual distinctions as sovereignty, policy and society create difficulties because with such reificated concepts becomes difficult, when not - implausible, to understand the political dynamics of the modern society. Moreover, the conception of centralized social order articulates a type of structuring functional systems characterized by precarious levels of functional and operative autonomy, in which the systems, thus differentiated, block or set up obstacles to the autorreferencial unfolding of the partial logics on the way to differentiation.

As it was indicated, in the institutional vertex of this particular form of structure has been located the referring political system and the State in its descriptive referent. Mascareño (2003) indicates that from the origin of the Republics the politic was, prescident of the legal legitimacy, the functional system that defined the features for the development of other spheres. Clear examples of this indiferenciation are the history of the states of emergency, emergency situation in Latin America (political-right indiferentiation). In the territorial background this concentric character acquired the centralization form. Specially the educative field, cultural and the economic one underwent their consequences during great part of the XX century.

Moreover, in our countries, the power historically -into the hands of the elite, descendant in its majority from the imperial colonialism-, articulated itself to generate the State-Nation (to homogenize the language, certain values and cultural conceptions, symbols and patterns) and the institutions of the society. Consequently, the historical reference of the civil society to the State and soon to the system of parties, as legitimate intermediary between the State and this one, that are instituting forms in which the political system (particularly in the strong Chilean institucionality) guarantees the social domination. An efficiency of the domination that, becoming strong in the State, finishes subsinking the social organization and drowning the call 'civil society' (State's corporation: Argentina, Mexico).

In the cultural field, the imperative of the transformation of the barbarism in civilization, that defined the state action by the means of the progress notion during great part of XIX century, was transformed into the XX's in the unit around the development idea, with which the local cultural differences were only acceptable in the measure in which they did not take part with those greater objectives. In the economic field the centralization was translated in urban industrialization and the handling planned and guided by the State of the substitution process of imports (policy-economy indifferentiation). (Mascareño, 2003).

By this, the development was transformed in an evolution hierarchically controlled by a functional system located to the peak of the society, the political system. This fact generated a particular form of 'differentiation/de-differentiation that coexists in the interior of the social order of the region, generating homogenous definitions which prevent the unfolding and the consolidation of the sistemical autonomy, every time the connections are transformed into processes of de-differentiation that while being replaced by functional substitutes and formulas of auto-understanding (clientelar relations, caudillism), make difficult the unfolding of the specialization of functions and the operativity democracy. 


\section{Law is Accepted But It is Not Obeyed}

... the life is not more than a nomadic ghost, a poor comedian who pavonea and is shaken during his hour on the scene: 'it is history told by an idiot.

Macbeth (W. Shakespeare)

Following this perspective, about the present, some social politicians and scientists, trusting in a supposed rationality and previsibility of the political decisions, still think that it is reasonable, starting from the operations of the political system and the State, to orient the economy, the education, the science and the right, that is to say the whole the society and the world. An agravade situation that, when does not become critic, for the low degree of the institutionalization of the expectations (cognitive - normative) and for the special historical form to make policy in the continent; the movementism or caudillism, in which all the development and attainment of the political-social and economical objectives have occurred through the fight of movements, situation that often was interrupted for the action of military coup.

That arise mainly with the crisis of the oligarchical state (decade of the '30) they tried to present an alternative political project (institutionalization not pluralist, fusion among the State, the politics and the society, for example Mexico (Zamorano Farías, 2017). In Asia and Latin America the political evolution was characterized for the growing of ethnic and classistic conflicts, repeated riots and frequent, popular violence, military coup d'etats, predominance of unstable leaders that often adopt disastrous social and economic politics, an extensive and flagrant corruption of ministers and public employeds an arbitrary violation of the rights and liberties of the citizens, decreasing levels of efficacy and bureaucratic capacity, a diffused alignment of the urban political groups, the loss of the authority legislatures and courts, and the fragmentation (and at times a total disintegration) of political parties with extensive bases of affiliated (Huntington, 1972).

These movements can be defined as forms of collective action that establish vertical relations between a charismatic leader and a mass who follows the presence and ideology of that leader, which have particularly essential characteristics (centered in values) and whose joints generate a strong horizontal identification between the subject members, everything defining the political action in a logical friend (the movementists) and enemy (the no-movementists ) determining therefore the political field. Style to make and to be of the politics; goverrnment by decrees, situations of violence and marginality, tensions among the political representation and the action of the State, exclusion, etc. Paradigmatic exponents of this characterization remain represented by the Latin-American populisms classics: G. Vargas in Brazil, J. D. Perón in Argentina and the Institutional Revolutionary Party (PRI) in Mexico.

The conjugating of these factors, although clarified, are central in the constitution and joint of the political culture in the Latin American societies of century and aims and mark the orientative logic of 'new' democracies, where this continues being a problem because there are not present some of the institutional aspects of the sociopolitical life conserving the typical characteristics of movementism and the functional de-differentiation (corporationism). For example, in Peru, where the governments of transition or new democracies, followed the historical form to understand and to do politics, that is to say, revived the movementist logical of the essentialist cut. In the region we return to see the figure of the charismatic leader that guides the masses in a setting that, evidently, is distant a great deal by the context where the classical populisms were generated. The important thing is to verify these recurrent phenomena and take them into account at the moment of the analysis.

This generates that the relation between policy and right also becomes critic because, and beyond the functional and operative differentiation that suppose as subsystems, when functionally differentiated operating, these are reciprocally linked through substantive operative benefits, every time the system of the right offers to the political system fundamental benefits as far as the legitimacy of the political decisions and the operativism of the premises for the use and application of the state monopoly of the violence, whereas the policy offers to the legal system the decisive premises in law form. Now, if the political system is the social system par excellence that has the capacity to integrate on the base of a taken selection (election), its function is only to coordinate in binding collective decisions those who make the decisions and those who are their object. But in this case, it requires necessarily the right as an operative channel that make functional and operative these decisions, as also the political benefits happen when binding decisions are precised in other functional systems.

But, without functional autonomy, the political representation and the right lose their capacity to guarantee procedures that maintain opened and increase the possibilities of election, variation and construction of alternatives. Recognizing that the political function cannot everything, and that it's much less able to transform the great ideals in fact, really but without her, it is lost an important element to support democracy. Otherwise, the auto-understanding forms only reinforce the yet fragile institutionalization in the continent (Fernandes Campilongo, 1997: 42, 43).

Then the problem is that in Latin America an enormous abyss between cognitive expectation and norm exists, whereas, 
for example, in the consolidated democracies there is a reasonable agreement between conduct and law. This situation is agravated by the particularitities of the historical development of the continent, where the process of normative learning permanently has been blocked through the closing of the spaces of public discussion and the maintenance of personal and collective dependencies respecting to the economic State and agents. This low level in the institutional construction is intimately bound to the forms that are assumed in the historical process of autoconstruccion of the civil societies, especially by the erosion in the constitutional legal agreements, consequence of practices and popular forms of social coordination.

Then, at the present although the democracy has a great possibility in the region, perceives a displeasure in relation to its operation, because a thing is to have `democracy and another to govern democratically at the level of the institutions, of the system of parties, the judicial or legislative power. Situation that remained clearly shown by the degree of distrust and apathy in a State as the Chilean one, according to the respective reports on human development of the PNUD (Santiago, Chile 1997, 2000, 2002, 2006, 2015, 2020).

This because together with the democratic impulse prevail strong limitations almost inherited from the Colonial time, and that have survived from the chaotic constitutionalism of the XIX century, to the recent authoritarian past. Limitations that raise interesting questions on the form in which these democracies operate and how they are possible. For example, in the South Cone the soldiers have not been calls to judgment by its violations to the human rights and not only this, but many times also continue acting like the power behind the throne. Being constituted, at last in factual powers that practically constitute a 'State' inside the State.

In such sense, one of the most critical aspects is given by the excessively integrate of our societies; that is to say, by the low processing of diverse sense (there is no plurality of languages), and by the form in which one exerts the executive authority and the fragility of the right to contain it. For example, in the region there is a general characteristic that the presidential institution became an excessive presidentialism almost obscene. As Sartori indicates (1996), under the intricate jurisprudence and normativism, the control of the Executive has been taken by the Presidents who were not in the republican sense of the word, but only emulous of the absolutism finishing of knowing not their institution, that moreover does not have the necessary counterbalance to limit the power (Bolivia, Brazil, Chile, Republic Salvador). From these excesses derived the diverse subspecies of the Creole presidentialism: the sátrapa, the caudillo or pretor, the patriarch, the cacique and the master of stay (Loveman, 1993).

The Chilean case turns out to be almost Kafkaesque, actually there is a civilian and military government because it remains consecrated in the Constitution of 1980. The speech of Chacarillas in 1977 specified very clearly that Constitution, indicating that the soldiers are the guarantors of the institucionality although the civilians exercise the government. The speech of Chacarillas does not speak of transition but of consolidation. In the rest of the continent the situation is not very different. The State in Latin America seem to be prisoner of autonomized institutions of the State, of diverse civil groups or religious or cultural institutions, of foreign actors (IMF-BM) or, as in some countries of the region, of groups joined to drug trafficking (Mexico, Colombia).

In addition, if to the previous thing we added the fact that virtually all the constitutions of the region contain clauses to create exception regimes where the elected presidents can act like constitutional dictators, for the ample definition of the term "emergency and for the repeated failures to create institutional balance to the exercise of power, the emergency powers are constituted, after all, in "the legal base of the dictatorship and the tyranny", as it indicates Loveman (1993), or in the substrate of the clientelism.

This form of clientelar coordination (that at the present becomes the civil pretorianism has been one of the practices that have more damaged the democracies of the region, preventing the real institutionalization of the cognitive expectations and doing violence to the norms, forming clientelar coalitions, almost "mafiose", that privatizing the communal property make implausible the benefits for the immense minorities, promoting, after all, the political and social instability.

The exclusion, consequently, the poverty and the lack of education are not accidental phenomena or exclusive symptoms of a low level of economic development, but endemic patterns in numerous countries and the region, that is a product of the coordinational clientelar logics that powered the corporative groups to the interior of our societies and that make impossible the informed monitoring of the authorities and of the institutions for a great part of citizens, because the operative institutes do not exist (of the right for example) or, in the best one of the cases, these are represented as anima. That is to say, they appear in constitutional texts but actually, they are accepted but not obeyed. During the so call conquer of America, the conquerors carried out the following ritual: when a law in form of edict arrived overseas, they respectfully placed the written text on their head and repeated; here the law is accepted but is not obeyed (la ley se acata pero no se obedece).

We indicated that the more evident sociopolitical characteristic substitute of the evolutionary happening in Latin 
America was the precariousness of the cognitive institution and the problems to make the right operative (norms). Instability and disfunction that are not the product of an institutional ossification but of understood forms, where a type of an integrating mechanism, the normative integration, comes being replaced gradually by a disintegrative and inadequate forms of systemical integration: the clientelar caudillism.

The revival of the clientelar caudillism, that Huntington in its modern variant denotes as praetorianis, is the result of a precarious and difficult evolution of the political institutionalization in relation to the socioeconomical development and the social mobilization, every time the development of the differentiated social order supposes a greater symbolism and a civilization of the expectations, as budgets of the communication (and not in the sense of introspection on the level of the conscience, as N. Elías supposed), but a society, whose logic of dominant coordination is the clientelar caudillism or the market, although complex and differentiated, lacks of institutional stability. Rather it is a society where the differentiation and indiferentiation appear to the same time.

That is the reason why the social differentiation and the increasing political mobilization are not followed by an increase of the institutional complexity and the result is a political acting without a political integration. That is to say, a situation where the social and political actors mobilize themselves without a simultaneous construction of the cognitive and normative institutions able to articulate and to add their demands. Therefore, although the different social sectors search for writing the right, shaping them in the language of the law, without a judicial power that works, those rights cannot totally be enjoyed, as it can be observed in the recent history of the continent (Zamorano Farías, 2003; 2017).

On the contrary, in absence of clear mechanisms of institutional mediation, the political and social forces confront each other openly, that is to say, its politicalization is not canalized by institutional mechanisms but consists of a no mediate war of everybody against all. The result is that, actually, the constitutions and the right become 'flexible' and the constitutional guarantees become 'uncertain' or are generally manipulated by a little but strong group of power.

We know that in the central societies the fundamental rights indeed have institutionalized and progressively extended themselves in successive waves of political, economical and social juridification then, indeed, what distinguishes the democratic system from the political or caudillistic forms is the praxis of stable institutional agreements. But in the political systems of the periphery, the weak institutions are at the mercy of minority social forces that 'colonize' with the objective to obtain private benefits. Even though these forces formally adopted the institutions, it does not happen to be an allegorical gesture because in fact, actually they are ignored or used functionally as a new instrument of domination (operative only for a part of them). For this reason, every time the political participation is increased, that results from the process of extension of the citizenship (fundamentally social) (Marshall, 1965), the democratic system strains and becomes incapable to establish suitable mechanisms of aggregation and intermediation of interests, leaving the door opened to authoritarian reactions or caudillistic manifestations.

For example, the sociopolitical fracture, completed during the government of Eduardo Frei Montalva in Chile (19641970), implementing a program that aimed to impel an accumulation model whose base was the great financial capital, persecuted to legitimize itself in the popular sectors by increasing processes of integration to its scheme of participation, but without the corelative legitimating institutional development, nor modifications in the social structure, mainly the related thing to the distribution of the property. The so-called popular promotion oriented to the increment of the integration and popular participation in the social life through the adequate implementation of organizations that would fortify the organicals that the same settlers had generated. Such situation elevated the degree of the social tensions and the intensification of the popular mobilizations, narrowing increasingly the manoeuvre margin and restricting the political options (Zamorano Farías, 2001).

A great part of these phenomena of politicalization mediated by a low institutionality, were explained on the originating of the interpretative base of some models of the culture, of the symbolic structures of the communication, or with resources referred to outer or objective conditions as the economic dependency, the isolation or the marginalization but, as it is clear in the previous example, when the increase of the societal differentiation and pluralism is not accompanied by the establishment of a more dense institutional structure, with the ability to establish and to handle the social complexity, the turbulences and the corporative power occupy that emptiness de facto. The institutional emptiness makes difficult the democratic operativity, in the sense of a relation between State, policy and society, which finishes again to reproduce the models of the movementist exclusion-inclusion: patrimonialism, favouritism or clientelar caudillism.

On the matter, a paradigmatic illustration, till the dramatic quality, of the phenomenon of a no mediated politicalization, is given by the military dictatorships. It is known that at a difference and in contrast to the military uprisings of the past (which were an integral part of the caudilescal game), the military dictatorships that arose throughout the Latin American political map, in the Seventy and Sixties, saw themselves as an original attempt to establish the institutional bases of a new political order that would solve the chronical problem of the clientelar caudillism, clientelar 'politic' and 
the marxist rhetoric.

The military dictatorships, whose political bases were given by the model of the neoliberal economy and by the 'Doctrina de Seguridad Nacional', committed themselves to recover the order through the decontamination of the society organizations and the 'normalization' of the economy. Its primary target was to contain the popular mobilization radicalized in the previous decade and the re-establishment of the order through the formula of the emergency situation. It was, according to some theoreticians, an answer to the decomposition of the capitalist model, to the cracking and crisis of the state display and the 'lost of legitimacy of the political regime' (Garretón, 1983; Lechner, 1995; Moulian, 1997; Zamorano Farías, 2003). The military autounderstood themselves as a solution to the problem of the caudillism and in addition, as the only over-political actors who still incarnated the contempted national values.

Evidently the coming of the military to power came to transform the function of the State of commitment into a repressive and vigilant State that eliminated the competitive political market and the traditional system of political mediations, subordinating the public space of the society in a new necessity of control and discipline of the population, imposing new forms of legitimation and obedience.

About the context of the clientelar 'way of doing policy', characterized by a no mediated politicalization, the military thought itself as the only actor able to act like a neutral de-political power against the politicalization. Only they would have been able to congregate the population towards unified national targets, because its traditional disdain for the policy located them as an impartial power able to rise on the policy. For this reason, it is not unusual that in the plane of the social participation, the military, using fundamentally repressive technics and legal reforms, promoted the 'order' through the atomizaton and fragmentation of the social weave, looking for the obedience and discipline of the population.

Nevertheless, the misfortune of the military for policy, particularly for the political parties, made difficult the process of the political institutionalization and generally their institutional proposals failed in providing effective mechanisms with the aggregation of suitable interests and intermediation. As a whole, this scene rather represented the pathetic manifestation of a deep disarticulation and atomizaton; the disorganizing effects of the historical matrix of the society, where the military did not manage stably different ways of social, economic, cultural and political order.

Practically, the military dictatorships were incapable to protect the State the colonization of the social powers and finished being victims of the same type of policy who came to fight. The description that O'Donnell (1994) makes of the tensions that constantly permeated the authoritarian alliance defies the notion of the authoritarianism as an extreme case of autonomy of the State, in which the State majestically reigns on the society. In fact, the 'bureaucratic authoritarive State' demonstrated a similar fragility and a propensity to be colonized by the private interests that seemed the praetorian State that was trying to replace. The assault, or auto-internal coup d'etat made by particular social groups, that took control of specific bureaucratic sectors to reach their deprived interests, mined the institutional rationality of the authoritarian bureaucratic State (O’Donnell, 1994).

So, the privatization of the state institutions contributed, as in the past, to the erosion, fragmentation and, finally, to the fall of the bureaucratic authoritarianis. But in this occasion, there were not docks to contain the destructive dynamics of the praetorianism, because the militaries had been victims of the politicalization; the state institutions were in fact indispensable to recover the order or did not exist or has been crumbled and disintegrated by the military machine (partly, some of these are the effects that the argentine and chilean society at the present undergoes). (O'Donnell, 1982).

It is evident then that the privatization of the political system by the military repression or the corporative groups by decrees, can temporarily disconnect the political system from the social atmosphere (to de-differenciate), but only the legality is able to establish independent institutional structures and to depoliticalize the institutional structures avoiding the resurgence of the clientelism. In this sense the sistemic perspective takes importance considerating that these phenomena can be explained with the weakness in the affirmation of the form of the functional differentiation and its coexistence with mechanisms of boundary of the exclusion that operate in a particular way; because, what doubts fits, here the governments have not been by laws but by men, may these be dictators, caudilles, presidents or buffoons.

Now, if the key to fortify the right, with faculties of operating the political decisions resides indeed in the clear differentiation between policy and right the certain thing is that, in the periphery of the society, the operative weakness of the legal system disables it to exert totally the faculty to canalize the political decisions, because although this one exists as text really it does not work. For that reason, the forms of authoritarian or clientelar inclusion continue reproducing the social contradictions by an organized political violence, informal economy or opened political corruption, each time they become substitutes of the modernity in modernity and that are transformed into structural impediments for an authentic functional and operative differentiation in the democracies of the region.

The fragile and precarious institucionality becomes a sufficient condition so that caudillistics or authoritarian logics of coordination can act there and prevail and the diverse forms of clientelar regimes can continue in an almost 
unpredictable and amazing succession, every time when not being associate with a form of particular government, can alternat with almost despotic and almost democratic regimes.

It can be sufficient to observe the case of the democratic transitions, where one of the maximum complications is given by the existence of a dual power; authoritarian (that 'relatively' diminishes) and democratic one (that tends to be increased, also 'relatively'), what reveals the clientelar logica that underlies them.

Then, to establish the problem of the political regime as the exclusive principle of the political development, without counting on the required institucionalism to crystallize this process, leads rather to a problematic theory of the institutionalization because the isolation of the political system of the social clientelar context is not sufficient in itself. The same institutions must be depoliticized, that is to say, autonomized for particular interests and powers, pointing that to institutionalize an expectation or to consolidate the functional autonomy of a system, it is irreducible to free the communication with all immediate commitment, of all the valuation, a necessary condition that makes possible to create the characteristical order in the modern society.

Otherwise, the political ways towards the institutional construction always conspired against the formation of independent institutions, or under the military dictatorships (or authoritarian regimes) where the State is colonized by the interests of the military themselves, by their allies or the clientelar caudillism with their logical leader - movement (J. Bolsonaro, N. Bukele, I. Duque).

Only the constitutionalization of the power of the State completes the process of undocking the State institutions from particular social strengths. It is on this base that in the consolidated democracies the law has sufficient social consent and the required institucionality so that it becomes difficult escaping, when not impossible. Here there is the importance in insisting that any form of authoritarian State is not sovereign; the sovereign State, in the modern sense of the term, is the product of the establishment of the empire of the law. Through general laws the constitucionalism eliminates the plurality of medieval privileges, locating the State as the sovereign political institution.

However, in Latin America, the law is something that the powerful people can ignore or haggle, a situation that when standardizing becomes expression of the hipertrofia of the system, because it blocks the sensitivity of the different subsystems and reduces the power of its autoimmunization. If the constitucionalism emancipates the institutions of the political logic, guaranteeing its coherence and institutional autonomy, a State legally constituted cannot depend on the will of the party, of the soldiers, of the Church, the factual powers of corporate groups, but in the legal norms specifically stipulated that impede, or complicate, the colonization and instrumentalization of their administrative apparatus on the part of private forces.

Consequently, it is not corrected to see the constitutionalism as a mere mechanism of limitation of the state power. The constitutionalism, that is to say, the autonomy and empire of the right, creates and organizes the power of the State, depoliticalizing the policy through the juridification. That is what constitutes the modern legal State, and in this sense, the constitutionalism comes to fortify the State since it constitutes an independent institution, separated from the myopia and the particularism of corporative forces. Schmitt yet indicated it: it is the constitutionalism that gives birth to the modern legal State since the juridification of the power of the State through the right and the State constitution as institution represents two faces of the same currency (Schmitt, 1982: 86).

Only the formation of a compatible institutional system with the degree of a social differentiation, characteristic of the modern complex societies, may be able to establish an effective constitutional complex, whose base supposes the total autonomy of the right, the policy, science, religion, etc.

But the low level in the institutional construction of the Latin American societies, intimately bound to the forms assumed in the historical process of auto-construction of their civil societies and the erosion in the constitutional legal agreements by a part of populistic forms of auto-understanding, disables such operation. This institutional deficit, strongly connected with the permanence of political forms of auto-understanding that erode the authority of the constitutionalism as an institution, causes and mixes with the sprouting of authoritarian populist movements that, through the instrumentation of its own constitutional mechanisms, undermine the authority of the law and the right as the institution. In absence of a cognitive institutionalization, of a real political culture and norm although the law exists but can not be accepted.

\section{Concluding Remarks}

Insomma, in front of the deficiency of an effective constitutional complexity, the right has been incapable to do its constitutional or regulative functions. The juridificaton, rather, tried to establish a process of no differentiated development, signed by the dramatic authoritarian and clientelar crises that continues generating recurrent necks of bottle in the political and social history of the region. Thus, with fragile cognitive and normative institutions, or in their absence, that establish and maintain the systematic limits, it is logical that the dynamic of the change of articles of incorporation assumes the form of a chaotic shocks between disordered sectorial logics and an increasing no-mediated 
politicalization; weakness that partly explains, and moreover under functional democratic regimes, the deficiency of rights with universal application.

Evidently, the success of the rules and norms are intrinsically bound to the institutionalization of an effective constitutional complex, because in the modern societies the principle of separation of powers must be extended beyond the stabilization of the political dualism/society towards a more comprehensive roll, that make possible to maintain and coordinate a differentiated plurality from the institutional logics. Otherwise, when the plausibility of any reform is " $a$ priori" too uncertain, every time the future also becomes uncertain; the cooperation strategies become improbable as the negotiations are made more and more difficult and troublesome when not being sustained in institutions that can delimit and really give exit to agreements, harnessing the vicious circle of the corporative coordination.

In other words, it's required a clear conceptualization of the paper of the right and the constitutionalism in the policy of the democratic consolidation, so that the fundamental rights not only protect the individual from the State but they also make possible to structure the atmosphere of the bureaucracy in way to consolidate the State as a subsystem of the society and to make reasonable a more effective and influential activity of communication, every time the cognitive-normative institucionalism becomes the most important bond of the democratic weave. That is to say, the institutionalism referred to the structure of the rights, the operations of the legal system and the apparatus that guarantee the sociocultural reproduction of the society.

But when observing the difficulties of affirmation of the democracy in the continent become manifest the resistance that have settled or structured in the passage from the stratification to the functional differentiation and that has received a significant weight in the development of the territorial boundaries made with the formation of the national states in the region. It is rather problematic, in peripherical societies oriented by a centralized order, when the intervention of the peripheric systems by the part of the central system corrupts the communicative sequence, knowing that it makes implausible the understanding of a new communication because the present system is not motivated to understand, but only to accept the imposed intervention.

Indeed, functional substitutes as the authoritarianism or caudillism have developed functions of stabilization, in the sense that come to reinforce the impediments from the differentiation, stabilizing forms of permanent destabilization of the operation codes in the system of the right and the policy, that reach levels of hipertrofia that would be, paradoxically, inexplicable without them. Perhaps the challenge may be to make stronger all the differenciated institutions, which, in spite of their imperfection, they maintain the actors to the interior of the rules of the democratic play. Otherwise, far from achieving the desired democratic aims of consolidation and reform of the market, they would revive the sterile authoritarian or clientelar patron.

Now, it is not the moment to plead only the existence of norms as magical formulas to solve all the problems, nor, as in fact it happens, to value the rules in themselves. Logically, the pure existence of rules only assures this fact (the law is acepted, but it is not obeyed), but if in our continent there would be a wish to go a step further on and to give a capacity to the utopical horizons of sense, it is a priority before everything that the consecrated rules and basic norms in the components must be effective. That is to say, that the right state must be operative and functional for all people, yes-no, no, saying precisely that the most important function of the right, through its operative structures (judicial power) is to gain and to conserve legitimacy by solving the conflict of the common people, generating confidence. Then only if we concentrate our attention in the ignored question of how the right can works in the most trivial things (functional differentiation and institutionalization of expectations), the state of right and the democracy will never consolidate in Latin America.

Finally, to insist on the necessary operativity of the right and the constitutionalism, that is, after all, the magna carta that allows us what we have to do, and at the same time that prohibits us what it is not necessary to do. Or, as it's said in the modern semantics, insisting on the functionality and operativity of the right and the institutionalism, referring to the structure of the operations of the legal system and to the apparatus that guarantee the sociocultural reproduction of the

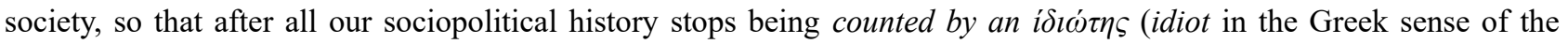
word. That is to say, person without reason, without ground).

\section{References}

BARALDI, C. (1996). Concept “diferenciación”, in Corsi, G., E. Esposito y C. Baraldi. Glosario sobre la teoría social de Niklas Luhmann. México: Anthropos Editorial, 56-58.

FERNANDES CAMPILONGO, C. (1997). Direito e democracia. Porto Alegre: Max Limonad.

GARRETÓN, M. (1983). Institucionalización y oposición al régimen militar: 1973 1980. Santiago: FLACSO.

HUNTINGTON, S. (1972). El orden Político en las Sociedades en Cambio. Barcelona: Paidós.

KOSELLEK, R. (1986). Futuro Passato. Per una semantica dei tempi storici. Genova: Casa Editrice Marietti S.p.A. 
LANGLEY, L. D. (996). The Americas in the Age of Revolution 1750-1850. New Haven: Yale University Press.

LECHNER, N. (1988). Un desencanto llamado postmoderno. Santiago: FLACSO.

LECHNER, N. (1995). Los patios interiores de la democracia. Subjetividad y política. México: Fondo de Cultura Económica.

LOVEMAN, B. (1993). The Constitution of Tyranny: Regimes of Exception in Spanish America. Pittsburgh: University of Pittsburgh Press.

LUHMANN, N. (1973). Ilustración Sociológica. Buenos Aires: Sur Editores.

LUHMANN, N. (1985). A Sociological Theory of Law. London: Routledge \& Kegan Paul.

LUHMANN, N. (1990). Essays on Self-Reference. New York: Columbia University Press.

LUHMANN, N. (1991). Sistemas Sociales. Lineamientos para una teoría general. México: Alianza Editorial.

LUHMANN, N. (1995). Poder. Barcelona: Anthropos Editorial.

LUHMANN, N. (1996). Confianza. Barcelona: Anthropos Editorial.

LUHMANN, N. (1998). "Causalità nel Sud”, in Corsi, G. e R. De Giorgi. Ridescrivere la questione meridionale. Lecce: Pensa Editore, 91-121.

LUHMANN, N. (1998a). Compeljidad y modernidad. De la unidad a la difeencia. México: Trotta Editorial.

LUHMANN, N. (2004). La política como sistema. México: Fondo de Cultura Económica.

LUHMANN, N. (2007). La sociedad de la sociedad. México, Herder Editores.

LUHMANN, N., \& R. De GIORGI. (1996). Teoria della società. Milano: Franco Angeli Editore.

MARSHALL, T. H. (1965). Class, citizenship and social development. New York: Doubleday and Company.

MARX, K., \& F. ENGELS. (1963). Werke Band 28, Berlin: Dietz Verlag.

MASCAREÑO, A. (2003). "Teoría de sistemas de América Latina. Conceptos fundamentales para la descripción de una diferenciación funcional concéntrica”, Santiago: Persona y Sociedad, 17, 9-26.

MOULIAN, T. (1997). Chile actual. Anatomía de un mito. Santiago: Editorial LOM.

O'DONNELL, G. (1982). El Estado burocrático autoritario. Triunfos, derrotas y crisis. Buenos Aires: Editorial Belgrano.

O'DONNELL, G. (1994). Delegative Democracy, in Journal of Democracy $N^{o} 5$, National Endowment for Democracy and The Johns Hopkins University Press, 55-69. https://doi.org/10.1353/jod.1994.0010

SARTORI, G. (1996). Ingeniería constitucional comparada. Una investigación de estructuras, incentivos y Resultados. México: Fondo de Cultura Económica.

SCHMITT, K. (1982). Teoría de la Constitución. Madrid: Alianza Universidad.

SPENCER-BROWN, G. (1979). The Laws of Form. New York: E. P. Dutton.

WHITEHEAD, L (1998). "State Organization in Latin America Since 1930", in Leslie Bethell (Ed.). Latin American Economy and Society Since 1930. Cambridge: Cambridge University Press, 3-98. https://doi.org/10.1017/CBO9780511626074.009

ZAMORANO FARÍAS, R. (2001). Entre la teoría y la acción. Dilemas sobre la acción colectiva popular Santiago de Chile: 1988-1992. México, Juan Pablos Editor.

ZAMORANO FARÍAS, R. (2003). Civilizzazione delle aspettative e democrazia nella periferia della società moderna. Lecce: Pensa Multimedia.

ZAMORANO FARÍAS, R. (2004). La democrazia dei postmoderni e i suo gesti allegorici. Lecce: Pensa Multimedia.

ZAMORANO FARÍAS, R. (2017). Observando el orden social en México: el sistema de la política y el sistema derecho. Juan Pablos Editor: México. https://doi.org/10.22201/iij.24484873e.2016.147.10647

ZOLO, D (1997). El léxico de Luhmann, in Camou, A. y J. E. Castro (Comp.). La sociedad compleja: ensayos en torno a la obra de Niklas Luhmann. México: FLACSO Editores, 239-256.

\section{Copyrights}

Copyright for this article is retained by the author(s), with first publication rights granted to the journal.

This is an open-access article distributed under the terms and conditions of the Creative Commons Attribution license which permits unrestricted use, distribution, and reproduction in any medium, provided the original work is properly cited. 